\title{
SUSPICIOUS SURFACES AND AFFECTIVE Mistrust In THE SOUTH CaUCASUS
}

\author{
Florian Mühlfried
}

\begin{abstract}
This article builds on ethnographic vignettes of mistrust, with the material stemming from the South Caucasus. Although mistrust has recently gained attention as a phenomenon sui generis, the impact of objects on the stirring of mistrust has been largely overlooked. The present article intends to fill this lacuna by investigating how certain objects are met with mistrust because their (material or discursive) surfaces and their contents seem inconsistent. The affective response to this perceived mismatch may be articulated in frustration or anger, but also in humor or longing. With respect to longing, I elaborate how this emotion stimulates searches for hidden truths that can be found in the realm of conspiracy theory.
\end{abstract}

Keywords: affect, agency, conspiracy theories, façades, mistrust, South Caucasus, surfaces

It took anthropology a while to discover mistrust as a topic in its own right. Previously, it was mostly present in passing, albeit with some relevant implications. The long-standing literature on African witchcraft, for example, has shown that witches thrive in a world saturated by mistrust toward one's neighbors and kinfolk (Ashforth 1998; Geschiere 2013; Stoller and Olkes 1987). Mistrust also features prominently in anthropological investigations of conspiracy theories, which have illustrated how assumptions about a hidden truth are often embedded in mistrust toward the obvious (Lepselter 2016; Marcus 1999; Pelkmans and Machold 2011; West and Sanders 2003). Additionally, social science-driven studies of corruption and fraud have brought to the fore how these phenomena abound in situations of essential distrust toward institutions (Haller and Shore 2005; Ledeneva 1998; Wiegratz 2016). 
But it probably needed the recent interest in phenomena that are usually represented as exceptions to the norm and problems for good life in order for mistrust to be considered a worthy object of investigation per se. In this spirit, the current emphasis on the flip side of positively connoted concepts has not only opened up pathways for investigating phenomena such as ignorance (e.g., Mair et al. 2012), remoteness (e.g., Saxer and Andersson 2019), and detachment (e.g., Candea et al. 2015) as fully fledged phenomena (and not just as problematic opposites). It has also questioned the 'fetish of connectivity' (Pedersen 2013), that is, the Durkheimian assumption that all that counts is that which relates (Strathern 2014).

Within this perspective, investigating 'negative' phenomena such as mistrust entails going beyond the connectivity paradigm and keeping an eye on practices of "disentangling from constitutive relationships" (Zigon 2014: 16). A handful of recent anthropological investigations of mistrust have been following precisely this agenda. Christian Giordano and Dobrinka Kostova (2002) have shown that mistrust is a reasonable strategy for detaching from and thereby coping with the everyday hardships of actually existing postsocialism. Matthew Carey (2017: 10) has gone to great lengths to show how mistrust occasionally creates spaces of "rugged autonomy and moral equality" and shapes a form of conviviality based on the stigmatization of exploitative relationships. In my own work (Mühlfried 2019, 2018), I have aimed to shed some light on the emancipative potential of mistrust by investigating its role in complicating the exercise of power. And a collection edited by Caroline Humphrey (2018) has aptly illustrated how attempts to avoid distrusted institutions eventually foster trust networks.

In these works, the definitions of mistrust vary, but most would probably agree with Carey (2017: 8) that "mistrust describes a general sense of the unreliability of a person or a thing." In addition to persons and things, one could add institutions as another potential source of mistrust. Whereas social interactions and confrontations with institutions feature prominently in the aforementioned works, they largely ignore encounters with things as crucial moments of experiencing mistrust. This is probably because in much of the literature both trust and mistrust are seen as genuinely linked to agency. According to Piotr Sztompka (1999: 20), for example, it is “improper” to express trust or distrust about a tree growing or the earth giving good crops, because such "purely natural objects" lack agency.

Irrespective of the problematic claim that trees and the earth are devoid of agency, certain objects in certain situations do in fact qualify as targets as well as triggers of mistrust-objects, however, that in all likelihood would not be classified as 'purely natural' by Sztompka precisely because they are seen as bestowed with agency. These objects are experienced as unreliable in the sense of Carey as they are believed to contain something (a 'dark' force, a suspicious 
agency) while at the same time concealing this content. More precisely, then, it is a perceived mismatch between the surface of an object and its content that ignites mistrust.

Such disparate objects are interpreted as 'false signifiers' that indicate either a presence as an absence or an absence as a presence. In the first instance, the surface is meant to hide the presence of an (at least potentially) evil or destructive force, like the Trojan horse that carried a hidden army of invaders. The surface of the horse distracted the enemies from the soldiers' presence and caught their interest; by letting the horse in, the enemies contributed to their own defeat. In the second instance, the surface indicates something that is not real, like Potemkin villages, which stand for something they are not-namely, a vivid, colorful, healthy and wealthy life. Instead of this life, however, the suspicious onlooker sees only a façade with nothing behind it.

Objects identified as Trojan horses and Potemkin villages are perceived as a means of impression management, but the kind of impression they are meant to make is interpreted differently. Whereas Trojan horses are harmless-looking objects that disguise an inimical presence in order to penetrate a protected area, the erection of Potemkin villages serves to hide a void. Distinguishing between these two forms helps to elucidate the kind of suspicion at stake. Whereas the interpretation of something as a Trojan horse illustrates the conviction that there is a malicious agent trying to conceal itself, the identification of a Potemkin village is based on the impression that a deceptive agent intends to create a falsely positive image of itself.

Treacherous façades can be material or non-material. Potemkin villages, for example, are often constructed from stones, and the Trojan horse used by the Greeks was made out of wood. In other cases, however, such façades are made out of words. For example, when it became public that the official report of the Exxon Mobile Corporation on the costs of climate regulation differed significantly from internal calculations, New York's Attorney General Barbara D. Underwood stated that "Exxon in effect erected a Potemkin village to create the illusion that it had fully considered the risks of future climate change regulation and had factored those risks into its business operations." ${ }^{2}$ The Trojan horse concept can also describe organizations set up to maliciously infiltrate a business environment or computer programs that seem helpful but end up "corrupting or demolishing the computer's software” (Merriam-Webster n.d.).

The perceived mismatch between surface and content often triggers sentiments of frustration, but also the longing for the 'real truth' that provides an explanation for this mismatch. Such 'truth' may be found in conspiracy theories. Conspiracy theories are particularly attractive to people who have lost trust in the apparent, because they seem to provide answers to questions such as "Why is it that the obvious and the real diverge? Who or what is behind the surface? What is real?" 
The following sections are meant to explore the social life of Trojan horses and Potemkin villages as well as the affective responses they produce and how these feed conspiracy theories. The objects of mistrust that I examine are both material and immaterial. The Potemkin villages are material; they are objects "that you can see or touch" (Cambridge Dictionary n.d.), but that seem unreliable because they do not coincide with reality. The Trojan horses are discursive products and thus immaterial. They are objects in the sense that they cause "particular feelings in or actions by others" (ibid.), in this case, feelings of mistrust related to the untrustworthiness of the discursive surface.

The case material stems from the South Caucasus, a region often said to be saturated by mistrust. This particularly applies to Abkhazia, a breakaway republic that is recognized by only six states internationally. Abkhazia split from the present-day independent country (and former Soviet Republic) of Georgia after a war in the early 1990s-a war it could win only with the support of the Russian Federation. Self-styled as independent, Abkhazia constantly has to struggle to preserve even the most basic forms of self-governance, not least in respect to the Russian Federation in the north. Sentiments of mistrust are widespread, not only toward neighboring countries, but also in respect to local politicians, who are widely blamed for siding with all kinds of unreliable forces.

Given that Abkhazia has seceded from Georgia and that Georgia, along with most other countries, does not accept Abkhazia's sovereignty, there is also mistrust between these two entities. This mutual mistrust is constitutive to the respective projects of state formation. From a Georgian perspective, Abkhazian statehood is seen as a façade that hides the presence of an evil force, namely, the Russians-akin to the exterior of a Trojan horse. From an Abkhazian point of view, the 'new Georgia' is suspected of being no more than a surface without substance-in other words, a gigantic Potemkin village. This image is based on the great efforts of the Georgian government to showcase itself as a dynamic, thriving, and successful state, manifested, inter alia, in Potemkinesque façades at the border to Abkhazia as well as numerous glass-walled police stations meant to represent modernity and transparency.

Certain parts of the populations, however, must get along with each other. This particularly applies to the Megrelians, a group that resides on both sides of the border and speaks a language related to Georgian-which, of course, makes them suspicious in the eyes of many Abkhazians who are concerned about the Megrelians' loyalty. In this highly fragile situation, shared mistrust toward vaguely defined dark outside powers, such as Freemasons in the form of conspiracy theories, provides a source of solidarity.

The ethnographic vignettes that are presented in this article are based on personal observations and conversations from various periods of time. The vignettes from Abkhazia originated during a six-month stay in 2017 and are 
largely based on my experiences in the Abkhaz capital Sukhum/i and the region of Gal/i. Those from Georgia stem from various periods of fieldwork between 2003 and 2019 that had mostly been conducted in the eastern region of Kakheti and in the Georgian capital Tbilisi.

\section{Trojan Horses}

Business or betrayal, so Timur Kodori asks in a Facebook post from 24 July 2017. The author, most likely using a pseudonym, is angered by the involvement of his Abkhaz compatriots in an international research project designed to preserve the Abkhaz language. ${ }^{3}$ The project is coordinated by the Georgianbased Center for Civil Integration and Inter-ethnic Relations and is funded in part by USAID, the US Agency for International Development. The participating linguists hail from the University of Frankfurt; their local partner is the Association of Businesswomen of Abkhazia. In his post, Kodori mentions the names of the participants as well as the amount of funding money they have been allocated. He then raises the question as to whether the Abkhazians involved in this project have been bribed by their opponents. By the latter, he refers to the Georgians, who fought and lost a war against Abkhazia in the early 1990s: "How soon will Abkhazia lose its independence as a result of such an approach and ... again become an appendix of Georgia?"

Another indicator of betrayal, according to Kodori, is the fact that the Abkhaz participants agreed to be photographed in front of a logo showing Abkhazia within the confines of Georgia. This logo is part of the corporate design of the Georgian NGO coordinating the research project. However, the home page of this NGO does not mention this project, not even in its annual reports produced during the project term 2015-2016. And maybe it is no coincidence that the 'current projects' section of the NGO's homepage was adjusted on 25 July 2017-one day after Kodori's post. The websites of the project partners in Frankfurt and Abkhazia do not contain a single word about this project either. Only USAID published the following description:

The goal of the activity is to foster people-to-people reconciliation between Georgians and Abkhazians through protection and promotion of the endangered Abkhazian language. This will be accomplished through: 1) mobilizing Georgian and Abkhaz academic and civil society around the common interest of preservation and revitalization of Abkhaz language; 2) connecting young people, potential leaders from Abkhazia and Georgia, to respect and advocate universal human values, encouraging them to foster mutual respect, tolerance and peaceful cohabitation; and 3) facilitating the meaningful dialogue on issues of common interest between diverse groups of society, including educational professionals, academics and young scholars and fostering the people-to-people cooperation. ${ }^{4}$ 
In addition to the promotion of cooperation, this project concerns the creation of an Abkhaz language corpus and the development of software for the linguistic processing of the Abkhaz language. The required material is provided by Abkhazians (among them writers), and the scientific expertise by the specialists from Frankfurt. Abkhazian linguists are not part of this cooperation, although they too are working on the documentation of the Abkhaz language and on concepts for its promotion. A linguist and teacher of Abkhaz based in the Abkhazian capital Sukhum/i who authored one of the few textbooks available had never heard of the project. A linguist from the Abkhaz Academy of Sciences found out about it from his dentist. The form of collaboration this project promotes is evidently asymmetric: one party delivers, the other one understands.

This colonial form of knowledge production confirms the mistrust of those who feel that Abkhazia is not being taken seriously. In this way, mistrust perpetuates itself and intensifies the rejection to work with colleagues from abroad, as cooperation is never assumed to take place among equals. A great deal of energy is needed for commitments with external actors whom one distrusts-energy that many Abkhazians lack after decades of isolation, stagnation, and depression. Further on, such kind of commitment could be dangerous and backfire. Given the clouds in which the project is shrouded, Kodori suspiciously assumes that one is not supposed to see what the project is really all about. ${ }^{5}$

This particular mistrust is ignited by a surface that is perceived as a façade. The suspecting assumption is that there is something hidden behind the façade: a political agenda based on hostile intentions. On the surface, one can see NGO-driven civic engagement that is presumably without a political purpose and directed toward a public good-in this case, the preservation, documentation, and promotion of the Abkhaz language. Underneath the surface, however, a distrustful observer such as Kodori identifies a dark force-in this case, the Georgian state and its allies. In order for this force to work, so Kodori implies, it has to come in disguise. This disguise is provided by the NGOs involved in this project, which are essentially machinations of masquerade.

Kodori's suspicion finds reverberations in 'big politics'. For the Russian government, too, most NGOs are carriers of alien forces in disguise-in other words, Western (secret) agents (Goncharenko and Khadaroo 2019). On the societal level, the majority of citizens of the Former Soviet Union (FSU) associate NGOs with the predatory capitalism of the wild 1990s and the concomitant political system that promoted transparency in discourse and closed-chamber dealings to the detriment of many in practice. Within this horizon of experience, the language of transparency as expressed in the above-mentioned project description published by USAID rather produces suspicions of opaqueness-a seeming paradox that has also been noted with regard to other parts of the world (West and Sanders 2003). 
Backed by this suspicion, the given research project appears as a cover-up of political infiltration and indoctrination to Kodori and his like-minded allies. Like a Trojan horse, it seems to serve those who intend to access the realm of their enemies by hiding in something that looks attractive and that invites the naive victims to take it home. The aim of this trick is to represent a presence that is not real and a reality that is not present. Trusting the visible would mean being trapped in illusion and falling victim to deceit. The distrust that Kodori articulates is meant to make the illusion disappear. His mistrust takes the direction of targeting those he perceives as enemies as well as their knowing or unknowing partners. He wants to make them visible and thus render them potentially accountable. He wants to unveil and substantiate his initial mistrust, which was mostly an itching feeling, a sensation that something was wrong. He wants to point to the cracks in the façade of the research project and show that something is there that should not be present.

\section{Potemkin Villages}

For distrustful onlookers, there is also the suspicious assumption that there is nothing behind observable reality. Everything is just a façade. By means of such façades, however, revolutionary projects occasionally indicate the beginning of a new era. One such project was the peaceful Rose Revolution in Georgia in November 2003. With the overthrow of the then president, Eduard Shevardnadze, the post-Soviet period was declared to have come to an end. A society would emerge that had freed itself from the shackles of the past. It would go from darkness to light-quite literally. In the more than 10 years since independence, frequent power cuts had turned the lights off. Now Georgia would shine.

The remodeling of Georgia started with fountains being dressed in pastel colors. Then the television tower in the Georgian capital Tbilisi was made to glitter like a Christmas tree. With the arrival of the former US president George W. Bush for a state visit in 2005, the apartment buildings adjacent to the airport were freshly painted. Blue and red rays of light illuminated the exteriors of old houses along the city walls at night. After the advent of lights and colors (cf. Ardzenadze and Dooley 2019), it was the time of balconies and cobblestones. The popular old town of Tbilisi, depicted in numerous novels and repeatedly painted or photographed, became the role model. From now on, every Georgian town would need a historic center with balconies and cobblestones. A large sum of money was invested in the development of Sighnaghi, a fortress town built on a mountainside overlooking the Caucasian mountain ridge. After cobblestoning and balcony building, this small town developed into the most popular tourist destination in the Georgian countryside. For Georgians, 
Sighnaghi now symbolizes regional development in the form of Disneyfication; for tourists, it is a symbol of Georgian authenticity.

In 2007, I visited a winemaker who works in a wine cellar in the neighboring town of Telavi. Telavi, too, has undergone a renovation of its old center. Traditionally, there had been no balconies in the center at all, but now they were being attached to many exteriors. Asphalt roads were being torn up and then paved with cobblestones. Shops, cafés, guest houses, and a center for tourist information had been opened. Nevertheless, there were hardly any visitors. Telavi at that moment was a ghost town. Perhaps spirits could work miracles and convey a sense of presence where before there was nothing, I speculated. The winemaker waved this off. Against the polished façades of the renovated center, it would become even more apparent how poorly people live. No state funds had reached them. "It's like in the Soviet Union-everything is just a travesty," the winemaker declared. ${ }^{6}$

The perception of the winemaker was largely shared. In a survey among the inhabitants of Telavi in 2014, the rehabilitation of the city center was unanimously dismissed because of the poor quality of the work, the sub-standard materials that were used, and the lack of coordination with the local population (Gilbreath 2014). One respondent concluded: "Telavi needed renewal, but not in the way in which it occurred. It was done in an absolutely ignorant way $\ldots$ in the opinion of the entire Telavi society" (ibid.: 3 ). The result of the governmental "terror tactics," as they were referred to by some in this survey, was a frustrating landscape of tacky and pointless façades.

Although the aim of this governmental approach was to make the Soviet past "forcefully obsolete in the present" in order to allow for "the emergence of western modernity and better life-styles in the future" (Khalvashi 2014: 13), the winemaker's comparison of the current governmental façade politics with that of the Soviet Union makes Soviet Georgia and post-Soviet Georgia look similar. What matters is what is in the plan-what can be presented to the media and celebrated by public events. In this vein, the Tbilisi airport was built at record-breaking speed, but once opened, its roofs began to leak. And 100 hospitals were built within three years (2007-2010), but their equipment had to be driven from one hospital to the other depending on the schedule of press conferences organized to document their inaugurations (Frederiksen and Gotfredsen 2017: 113-118).

In the Soviet Union, the realization of plans had also been detached from reality, dramatically so and with substantial consequences. There was no longer anything behind the surface; instead, the surface was employed as a material that could be manipulated and ironized (Yurchak 2006). In post-Soviet Georgia as well there is nothing behind the façades-so, at least, many Georgians assume. For them, this "monumental vacancy" (Holt 1979: 55, citing Smithson) reflects the emptiness of neoliberal politics that comes with great 
pomp but with little benefit for them. Somebody, however, is responsible for this emptiness of politics and for erecting façades with no substance behind them. And it is this agent that is a source of anger for those who feel fooled. After all, the remodeling of towns like Telavi was seen as a form of governmental 'terror tactics'. The winemaker not only asserted that the state-funded development of Telavi was a travesty, but also mocked the Georgian state for treating its citizens like children who can be impressed with glitter. The perceived mismatch between surfaces and substances, in this case, is the result of state-sponsored impression management gone wrong.

The newly erected façades attempt to signify something that they are not. The painted apartment blocks close to the airport, the exteriors of cracking old Tbilisi houses now bathed in flashy colors, hospitals with no equipment-all this evokes the image of Potemkin villages. These fake villages, allegedly (for it may be a rumor) built by Grigory Potemkin for Catherine the Great in 1787, represent grandeur without substance, serving to hide an undesirable presence. And this architectural dazzling, which became paradigmatic under the label 'Potemkin villages', is at stake in post-Soviet Georgia as well. This dazzling mostly affects those unfamiliar with the context. Knowing 'too much', by contrast, raises the likelihood that the façades of Potemkin villages become surfaces for the projection of suspicion and mistrust. For those who 'know' are able to 'see' the con man who is trying to hide behind the façade.

\section{Theoretical Implications}

\section{False Signifiers}

In the two cases portrayed above, surfaces become sources of mistrust because they are interpreted as signifiers of a content that they lack. Such a mismatch may provoke the suspicion that there is a concealed secret agenda. This suspicion is often raised by perceived cracks in the surface that seem to allow glimpses into the underneath. In this vein, Timur Kodori assumes that NGOs occasionally provide the façade behind which a secret political agenda unfolds. He sees the research project that he is targeting as a Trojan horse that allows the enemy to penetrate one's own space. What he discerns is a contradiction between visible surfaces and that which is beneath them; and it is this contradiction that points to treason and raises his anger. The façade of the project is thus interpreted as a false signifier that represents a presence as an absence. His mission, consequently, is to reveal the agency that tries to conceal itself.

As to the Georgian political agenda, the suspicion is that there is nothing behind façades, that the surface is all there is. This absence of substance comes in stark contrast to the message that is conveyed with these façades-that of 
a presence, of a thriving life, of a succeeding present and a future. This message, however, is largely distrusted. Instead, the façades are perceived as acts of deceit by significant parts of the Georgian populace. In other words, they are also interpreted as false signifiers, albeit denoting an absence as a presence. This perception perpetuates the feeling of frustration. There should be something, but there is not; everything is just a façade. The belief that façades are acts of deceit also denotes an untrustworthy agent, namely, the Georgian state, that is blamed for trying to cheat its citizens.

\section{Affective Mistrust}

The mistrust provoked by a surface that is supposedly charged with meaning it actually does not contain produced affective resonances that manifested in anger and/or frustration in the above-mentioned cases. Kodori, who sees the NGO project as a cover-up of political infiltration, is angry about the participation of his compatriots in this act of deceit and those who hide behind façades. Similar to the Wutbürger (angry citizens) hitting the German streets, he is aggravated by a sense of being fooled and betrayed and seeks to transform his anger into political activism. ${ }^{7}$ The Potemkin villages that have recently been built in the wake of the Rose Revolution all over Georgian small towns to simulate a future that has not yet arrived also stir negative feelings. Some Georgian citizens are angry that their government seems to assume that they are too stupid to see the missing reality. Others are fairly frustrated by the lack of substance of current governmental policies. ${ }^{8}$

Frustration and anger are by far not the only emotional responses to the perception of a mismatch between surface and content, however. It can also be experienced as comical or ironic, as Alexei Yurchak (2006) has masterfully illustrated in respect to the late Soviet Union. After all, a surface that is more or less detached from any essence can be mocked in such a way that any claim to authenticity is ridiculed. And this (at least temporary) suspension of claims to authenticity may come across as a true relief and source of pleasure and satisfaction. For example, the Potemkinesque façades that have been erected all over the capital, and the gloomy colors they are bathed in, frequently trigger jokes and making fun. As in other Disneyfied cities in the post-Soviet sphere, such as Astana, these hyperbolic sites are nevertheless part of identification processes, not least precisely because they are hyperbolic (Laszczkowski 2016). Trojan horses, however, are less frequently the target of jokes, because they-if taken seriously-are carriers of danger. It is only when the façade is dismantled that there is a space for laughter; until then, anger and fear prevail.

In situations of abundant mistrust, however, detaching surfaces from their 'obvious' meaning can be a cause for relief. If things are not (only) what they seem to be, there is some 'real' substance to be detected. If things are not what 
they are said to be, there is some truth to be found elsewhere. This truth is comforting, and it can be shared, providing a sense of belonging and a source of solidarity for the potential victims of deceit who have awakened, opened their eyes, and seen the truth. It is this mistrust-driven longing for the truth and this search for comfort that I turn to in the final part of the article.

\section{Conspiracy Theories}

Visiting a Megrelian family in Gal/i, a town in Abkhazia close to the 'border' with Georgia. Giorgi, a Megrelian nationalist, is seated next to me. For him, the first kingdom of the Megrelians, Colchis, represents the origin of Georgian statehood. Only the Megrelians and the 'hill tribes' (Georgian highlanders such as Svans, Tushetians, or Khevsurs) are true Georgians, he postulates, the others are mixtures of Georgians, Armenians, and Azerbaijanis. ${ }^{9}$ He has learned Abkhaz as a child and has Abkhazian friends. In front of me are two Abkhazians who speak Abkhaz among themselves and Russian with the others. In order to explain how the war between Georgia and Abkhazia came about, Giorgi tells a story he attributes to the erudite Georgian nobleman Sulchan-Saba Orbeliani:

A pig and its piglets live at the foot of a tree on which an eagle nests. Comes a fox and says to the pig: Do not leave the tree [to fetch food]; the eagle is just waiting to kill your piglets. Then he goes to the eagle and says: Do not fly away [to search for food for the eaglets]; the pigs are just waiting to gnaw away the root of the tree until it falls over. The pig and the eagle no longer leave the tree. The first piglet dies and is fetched by the fox, the first eaglet dies and is fetched by the fox. At the end, everyone is dead and the fox has filled its stomach.

Giorgi explains: "A third force is at work here, which whispers, incites, and only pursues its own interests. This force was behind the war in Abkhazia, this force is behind everything: Jews, Freemasons."

This note is included in my diary for August 2017 when I visited a town whose name is being disputed. Some call it Gal and see it as the easternmost city of Abkhazia. Others call it Gali and thus perceive it as a Georgian city, because the ' $\mathrm{i}$ ' is the nominative ending of Georgian nouns. Its population was displaced by Abkhazian troops after they had won the war against Georgia in the autumn of 1993. Violence came suddenly, unexpectedly, and massively: people had to flee overnight. ${ }^{10}$

The expulsion was based on Abkhazian troops' and leaders' distrust of the loyalty of the population of $\mathrm{Gal} / \mathrm{i}$, which almost completely consisted (and now again almost completely consists) of Megrelians. They speak a language related to Georgian, and most of them live on Georgian territory across the border. As a second language, almost all Megrelians speak Georgian, the 'language of 
the enemy'. In the second half of the 1990s, shortly after their displacement, a large number of Megrelians were able to return to their destroyed homes. The Abkhazians' distrust of the Megrelians, however, remains alive today. Abkhazian police patrol the streets; Megrelians are not recruited. Megrelians are denied Abkhazian passports, unless they profess to have been originally Abkhazian and megrelianized later on. In 2014, Megrelians residing in Abkhazia were deprived of the right to vote. The Georgian government speaks of apartheid. And in 2015, the Georgian language was banned from use in the schools of Gal/i. Despite their poor command, Megrelian children thus have to study school subjects in the Russian language.

Georgians, too, distrust Megrelians because their group provides numerous features that could justify national independence: a separate language, a fairly clearly demarcated settlement area, and periods of political sovereignty (see Broers 2001). For this reason, Georgian scholars attach great importance to concepts. Whereas the Georgians are considered an ethnic group, the Megrelians are labeled as a sub-ethnic, ethnographic, or ethno-territorial group. ${ }^{11}$ Beyond academic concerns, the crucial issue here is that ethnic groups may become a nation and claim sovereignty according to international law, whereas groups allocated below the threshold of ethnic identity may not, because they already belong to a (at least potential) nation. As an ethnic group with its own language, Megrelians may well claim sovereignty outside of the confines of the Georgian state, and this claim would be difficult to dismiss on scholarly grounds. The background to these concerns is separatism, which has lead to the de facto statehood of Abkhazia and, to a lesser extent, of South Ossetia. This issue has motivated some Georgian scholars to state that Megrelians speak a dialect of Georgian, not a language (see, e.g., Gogebashvili [1902] 1990), although the vast majority of linguists worldwide disagree (Harris 1991).

In the district of $\mathrm{Gal} / \mathrm{i}$, mistrust is omnipresent, mutual, and reciprocal. The reciprocity of mistrust is self-perpetuating, creating spirals of suspicion that are almost impossible to escape. When mistrust encounters itself, it tends to intensify and solidify, just as aggression escalates in situations of war. Yet the citizens of $\mathrm{Gal} / \mathrm{i}$ long to find ways to get along with the presence of others whom they distrust and who distrust them. One promising way is to allocate the core of mistrust beyond subjective accountability. Instead of blaming the people in one's surroundings for the unbearable situation, one may assume that there is something else behind the surface, an evil force that drives it all and causes mistrust to spread. For Giorgi, this evil force is made up of quasi-fictional and locally unrepresented groups such as Jews and Freemasons, which are pitting locals against each other in the pursuit of their own interests. One has to seek below the surface, so Giorgi believes, in order to understand what is really at stake.

Such narratives make it possible to live with those who distrust you because they are not held responsible for this distrust. And one can agree with them 
about invisible enemies who are to be blamed for it all. Later on, I note: "Many conspiracy theories. Armenians, Jews, Freemasons are guilty of everything, but one cannot see them and there is no evidence (a hidden power that, like God, works in secret)." As much as these conspiracy theories are based on the demonization of groups such as Freemasons, Jews, or Armenians-with potentially most harmful consequences such as pogroms, ethnic cleansing, shootings, incacerations, or gasification-they allow for ways of getting along with one's 'own' others, who are apparently, or so it seems, not responsible, just like oneself. Thus, conspiracy theories may open up a shared space-a space that potentially nurtures conviviality, if only in its most basic form. ${ }^{12}$ It is the 'comfort of commonly perceived enemies' (Asmussen 2011) that conspiracy theories provide. The secret others become scapegoats, and their joint blaming creates commonality (see Girard [1972] 2005). ${ }^{13}$

The conspiracy that Giorgi alludes to is widely shared not only in Georgia and Abkhazia, but in many other post-bloc societies. Almost irrespectively of political affiliation, it blames Jews, Freemasons, or Armenians for a perceived evil. The former Georgian president Mikheil Saakashvili, for example, is stated to be Armenian by his opponents-and thus evil by nature. ${ }^{14}$ The presumable Jewish conspirers are often mentioned to be personified by George Soros, who, by sponsoring various branches of the Open Society Foundation, did actually have a serious impact on political developments, for example, in Georgia. The alleged conspiratorial workings of the Freemasons are also frequently attributed to Soros and his Foundation. As there are but very few openly selfidentifying Freemasons in the South Caucasus, they are the most abstract of the groups of purported conspirators, often said to be behind the activities of international finance-related institutions such as banks, real estate agencies, and so forth. This is where Giorgi's assumption that Freemasons and Jews are 'really' behind the war between Abkhazians and Georgians comes into play. Since these groups are believed to be primarily interested in moneymaking, they allegedly support wars as opportunities to do so.

\section{Displacing Agency}

By insinuating a malicious agent behind an object's surface, conspiracy theories relocate agency to an outside world beyond direct access and control. In this sense, conspiracy theories can be construed as occult cosmologies, since they too insinuate that "power originates in the unseen realm and has visible effects in the everyday world" and that the everyday world "is simply a facade that masks a deeper, more important and 'real reality', one that lies beyond our immediate comprehension" (Sanders 2003: 160). Such a perspective on conspiracy theories echoes recent calls to look at what they do instead of what they are (Çaylı 2018). Viewed by Stewart (1999) as a social practice, such 
theories foster a "displacement of the meaning of action" (Humphrey 2003: 180 ) to the realm of the invisible as a way to conceal people's agency, but also to articulate "collective suffering" (ibid.: 192-193).

The kind of conspiracy theory spread by Giorgi levels the difference between aggressor and victim and suspends questions of guilt and responsibility. It primarily reflects the concern of the most vulnerable group in this setting-the Megrelians-to overcome mutual mistrust with their Abkhazian neighbors. By "separating the space of power's formulations from that of its operations," conspiracy theory here works as a "spatial practice" that eventually makes landscapes of mistrust habitable (Çaylı 2018: 255).

\section{Conclusion}

Mistrust, according to Matthew Carey (2017: 10), is often a response to the experience that "other people are, in some sense, unknowable per se. That they cannot be sounded or fathomed; their personality cannot be identified or used as a basis for prediction." Experiences with institutions whose doings are perceived as opaque (and thus unknowable) may have a similar effect; they often stir mistrust and the desire to keep a distance (Humphrey 2018). As the case examples from the Caucasus have shown, however, mistrust is ignited not only by assuming to know too little, but also by assuming to know too much about something in order to take it at face value.

For Timur Kodori, there are clear signs that the international research project on the Abkhaz language is a treasonous fabrication. Convinced that he knows more than is being revealed, he perceives the surfaces of the project and of the NGOs involved as ways of concealing malevolent intentions-as false signifiers that represent a presence (of hostile agency) as an absence ("just a research project”). Nevertheless, Kodori also sees cracks in the façade that allow glimpses into the hidden content. Motivated by these cracks, Kodori would like to know more. He wants to find out about the 'real' essence that is hidden and spread this knowledge among his compatriots.

Giorgi also believes to know too much, which prevents him from taking things for what they are allegedly meant to be. For Giorgi, what is seen on the outside-Megrelians and Abkhazians at odds with each other-is just a play staged by a third party, which he identifies as a conspiracy of Jews and Freemasons. The actors who can be seen onstage, so it follows, are not the ones who have written the script. And in contrast to 'real' actors, they are not even aware of it. They are more like puppets who are devoid of any agency and are thus the tools of someone else. In this sense, the surface is not a false signifier since it does not denote an absence as a presence or a presence as an absence; rather, it is a sad reminder of the absence of agency of people who perceive themselves 
as agents. In other words, the mismatch between the surface and the content is one of confusing, and confused, agency. The victimizing effect of this narrative has palpable and positive effects on the ground, however, as it places both Abkhazians and Megrelians in the same category: no longer adversaries, they become 'folk', juxtaposed to 'those in charge'.

Conjuring up an external evil agent in a situation of omnipresent mistrust in the Gal/i district of Abkhazia is functionally equivalent to evoking an external benevolent agent as religion does. Indeed, the $\mathrm{Gal} / \mathrm{i}$ district is saturated not only by conspiracy theories, but also by religious narratives, as I have frequently noted in my fieldwork diary and outlined elsewhere (see Mühlfried 2019: 76-78). The relocation of 'true' agency mirrors a concern with everyday realities and their common representations. In other words, they contain more than a grain of mistrust toward those experts representing and explaining reality. After all, adherents of conspiracy theories such as Giorgi question the expertise of 'mainstream' political analysts and journalists to understand what is really at stake, and of politicians to do their job accordingly.

This may help to explain why 'alternative truths' in the form of conspiracy theories or religion are so popular in and around $\mathrm{Gal} / \mathrm{i}$ and are gaining popularity in other regions that are increasingly affected by mistrust in experts, including Western countries. ${ }^{15}$ The longing for truth allocates the latter to the realm of the hidden that, in the eyes of the converts, can only be seen by those who have learned how to look behind the façades. On this account, the global movement of COVID-19 deniers bears traces of a religious movement, with 'truth' allocated beyond visibility and the conviction to be born again (and thus detached from the rest of the world) after having seen the 'truth'.

It is this dialectic of trust and mistrust in the (re)making of sense and the (re)construction of selfhood that recent anthropological investigations of trust regimes have brought to the fore (Broch-Due and Ystanes 2016; Liisberg et al. 2015 ) and that the findings of this article substantiate. When trying to understand the current inflation of conspiracy theories, then, it may be helpful to abandon the concern with the life-worlds they insinuate and instead analyze the regimes of mistrust and doubt that they are embedded in (see also Pelkmans 2013). Such an approach would resonate with other recent works that have investigated phenomena designated with the prefix mis- or dis- as not just absences, but as productive forces. For mistrust may be the beginning of something, perhaps even of trust. 


\section{Acknowledgments}

In the various stages of the development of this article, I greatly profited from comments by Martin Demant Fredriksen, Ketevan Gurchiani, Judith Bovensiepen, Hans Steinmüller, Paul Manning, Tamta Khalvashi, Mariam Shalvashvili, David Leupolt, Kerstin Klenke, and two anonymous reviewers. Also appreciated is feedback I received during a presentation at the Manchester Social Anthropology Seminar in February 2020 and a lecture for the Heinrich Boell Foundation in December 2018 in Tbilisi. Some of the material features in my 2019 book Mistrust: A Global Perspective. I am also greatly indebted to Shawn Kendrick for excellent copyediting.

Florian Mühlfried is a Professor of Social Anthropology at Ilia State University. He has been a Lecturer at the Tbilisi State University, a Research Fellow at the Max Planck Institute for Social Anthropology, a Visiting Professor at UNICAMP, Brazil, and an Assistant Professor at the Friedrich Schiller University Jena. His publications include the monographs Mistrust: A Global Perspective (2019) and Being a State and States of Being in Highland Georgia (2014), the edited volume Mistrust: Ethnographic Approximations (2018), and the co-edited volumes Sacred Places, Emerging Spaces: Religious Pluralism in the Post-Soviet Caucasus (2018) and Exploring the Edge of Empire: Soviet Era Anthropology in the Caucasus and Central Asia (2011). E-mail: florian.muehlfried@iliauni.edu.ge

\section{Notes}

1. Carey (2017: 8) contrasts this approximation to mistrust with a take on distrust that characterizes the latter as "based on a specific past experience." Although, according to Merriam-Webster (1984: 263), the terms 'mistrust' and 'distrust' are largely used interchangeably in quotidian parlance, I will in the following refer to distrust as a particular and rather focused response to an object and to mistrust as a more general, 'fuzzy', multi-layered, and multidimensional phenomenon.

2. See the October 2018 summons issued by Underwood to Exxon at https:// ag.ny.gov/sites/default/files/summons_and_complaint_0.pdf. In a similar vein, the political analyst Stefan Meister refers to the Collective Security Treaty Organization (an international military alliance in Eurasia led by Russia) as a "Potemkin organization" because it provides security for its members such as Armenia only on paper. See https://www.boell.de/de/2020/11/18/krieg-undwaffenstillstand-bergkarabach-10-konsequenzen-fuer-den-suedkaukasus-unddie-eu. Unless otherwise indicated, translations are my own. 
3. The question of who was behind this pseudonym caused quite a debate. Some suggested that the author might be a woman, using a male pseudonym to distract from her identity. Others speculated that he or she might not be Abkhazian but rather a foreigner, maybe a Russian.

4. This text can be viewed as archived content at https://2012-2017.usaid.gov/ georgia/working-crises-and-conflict. It appears under the heading "Preservation of Abkhaz Language by Abhaz and Georgians (PALAG), Sep 2015-Sep 2017, Center for Civil Integration and Inter-Ethnic Relations.”

5. A similar kind of distrust, however, has been articulated in respect to the author of this Facebook post. Given that the male name Timur Kodori could be the pseudonym of a woman (as mentioned earlier), the reader may also not be meant to see what is real-the identity of the post's author. The possibility that Kodori was a foreigner in disguise nurtured the suspicion that the author's prime intention was to raise conflict and confusion in Abkhazia, and hence to serve the aim of 'foreign powers'. What this illustrates is that those who articulate their mistrust are often viewed with suspicion, a mutual process that creates an endless cycle of mistrust.

6. Similar viewpoints have been voiced by inhabitants of the Azerbaijani capital Baku, who perceived the remodeling of their native city in the early 2000s as congruent with Soviet impression management. These impressions indicate an uncanny continuity between Soviet architecture and postmodern architecture that, some say, is driven by the desire to erase visual memory (Grant 2014: 520).

7. This anger and the perceived need to act are expressed well in the lyrics of the song "Marionetten," released in 2007 by the band Söhne Mannheims, which is popular among German right-wing populists: "And because you're twisting the facts again/We will intervene."

8. A similar frustration has already been noticed by Pelkmans (2003) during his fieldwork in the early 2000s in the Georgian province Adjara. In that case, it was mainly voiced by members of the intelligentsia, commenting on the uselessness of state-sponsored architecture for the public.

9. This narrative is at the heart of Megrelian nationalism. It states a privileged status as one of the oldest and most authentic groups of people co-conceptualized as Georgians and is shared with other marginalized groups such as the Svans, whose loyalty to the Georgian state is also frequently questioned by 'mainstream' Georgian nationalists. In this context, the narrative represents Megrelians as 'pure' and 'authentic' Georgians-more 'authentic' than lowland Georgians 'tainted' by their mixed relations with nationalities such as Armenians and Azerbaijanis. In other contexts, such as the one in Abkhazia, the very same narrative helps to sustain a representation of Megrelians as exceptional, as a special group with its own history, tradition, and language, which could be dealt with on its own right. For more details on Megrelian nationalism, see Broers (2001).

10. In accordance with the policy of the independent media portal OC Media, which reports on the entire Caucasus region, I do not use qualifiers such as 'de facto', 'unrecognized', or 'partially recognized' when discussing institutions 
within Abkhazia for reasons of readability. In the same vein, the simultaneous usage of the designations 'Abkhazia' and 'Georgia' does not imply a position on the political status of Abkhazia, but rather follows the pragmatic goal of being able to contrast situations and developments in Abkhazia and (the rest of) Georgia without straining readability with inserted brackets.

11. See, for example, Chit'aia (1997-2001), who prefers the term 'sub-ethnic'.

12. See West and Sanders (2003) for the social workings of conspiracy theories.

13. In the Gal/i district of Abkhazia, there are no Jewish or Masonic organizations and only a few Armenians, who do in fact have to face discrimination, not only from ethnic Abkhazians, but from Megrelians as well. In the South Caucasus, Armenians are frequently addressed with the same stereotypes as Jews elsewhere.

14. On the Internet blog Quora, a commentator declares that Saakashvili "is well known to the locals of Georgia and Armenia for being a bastard of an Armenian parent. [Though] it is apparent even from his surname and [though] his family story was published many times in the local mass media, he actively denies his Armenian ancestry all his life." See https://www.quora.com/Whyis-Mikheil-Saakashvili-so-disliked-in-Armenia-Why-do-many-Armenianshate-him.

15. The 2017 Edelman Trust Barometer documented a dramatic decline of trust on a global scale, not only in politics and the economy, but also in the media and NGOs - a process the pollster summarized with the trenchant formula of a 'meltdown of trust'. In the two years since then, the general populace continued to largely distrust institutions allocated in the mainstream. The resulting condition is one of fundamental political alienation. According to Edelman's 2019 report: "Only one in five feels that the system is working for them, with nearly half of the mass population believing that the system is failing them." See https://www.edelman.com/sites/g/files/aatuss191/files/2019-02/2019_ Edelman_Trust_Barometer_Executive_Summary.pdf.

\section{References}

Ardzenadze, Edo, and Patrick Dooley. 2019. "The Neon Revolution of Tbilisi.”

Post Pravda Magazine, 22 January. https://www.postpravdamagazine.com/theneon-revolution-of-tbilisi/.

Ashforth, Adam. 1998. "Reflections on Spiritual Insecurity in a Modern African City (Soweto).” African Studies Review 41 (3): 39-67.

Asmussen, Jan. 2011. "Conspiracy Theories and Cypriot History: The Comfort of Commonly Perceived Enemies.” Cyprus Review 23 (2): 127-145.

Broch-Due, Vigdis, and Margit Ystanes. 2016. "Introducing Ethnographies of Trusting." In Trusting and Its Tribulations: Interdisciplinary Engagements with Intimacy, Sociality and Trust, ed. Vigdis Broch-Due and Margit Ystanes, 1-36. New York: Berghahn Books. 
Broers, Laurence. 2001. "Who are the Mingrelians? Language, Identity and Politics in Western Georgia." Sixth Annual Convention of the Association for the Study of Nationalities 2001. Panel: "Minority Identity in Georgia.” Unpublished paper.

Cambridge Dictionary. n.d. “Object.” https://dictionary.cambridge.org/de/worterbuch/englisch/object.

Candea, Matei, Joanna Cook, Catherine Trundle, and Thomas Yarrow. 2015. "Introduction: Reconsidering Detachment." In Detachment: Essays on the Limits of Relational Thinking, ed. Matei Candea, Joanna Cook, Catherine Trundle, and Thomas Yarrow, 1-31. Manchester: Manchester University Press.

Carey, Matthew. 2017. Mistrust: An Ethnographic Theory. Chicago: HAU Books.

Çaylı, Eray. 2018. "Conspiracy Theory as Spatial Practice: The Case of the Sivas Arson Attack, Turkey.” Environment and Planning D: Society and Space 36 (2): 255-272.

Chit'aia, Giorgi. 1997-2001. Works in Five Volumes. [In Georgian.] Tbilisi: Mecniereba.

Frederiksen, Martin Demant, and Katrine Bendtsen Gotfredsen. 2017. Georgian Portraits: Essays on the Afterlives of a Revolution. Winchester: Zero Books.

Geschiere, Peter. 2013. Witchcraft, Intimacy, and Trust: Africa in Comparison. Chicago: University of Chicago Press.

Gilbreath, Dustin. 2014. "Transforming Sites of Memory, Transforming Time: Telavi's Rehabilitation.” Caucasus Analytical Digest 66: 2-5.

Giordano, Christian, and Dobrinka Kostova. 2002. "The Social Production of Mistrust.” In Postsocialism: Ideals, Ideologies and Practices in Eurasia, ed. C. M. Hann, 74-91. London: Routledge.

Girard, René. (1972) 2005. Violence and the Sacred. Trans. Patrick Gregory. New York: Continuum.

Gogebashvili, Iakob. (1902) 1990. “An Evil Intention vis à-vis Mingrelia.” [In Georgian.] In Collected Works in Five Volumes. Vol. 2, 357-360. Tbilisi: Ganatleba.

Goncharenko, Galina, and Iqbal Khadaroo. 2019. "Disciplining Human Rights Organisations through an Accounting Regulation: A Case of the 'Foreign Agents’ Law in Russia.” Critical Perspectives on Accounting 72: 102-129.

Grant, Bruce. 2014. "The Edifice Complex: Architecture and the Political Life of Surplus in the New Baku." Public Culture 26 (3): 501-528.

Haller, Dieter, and Cris Shore, eds. 2005. Corruption: Anthropological Perspectives. London: Pluto Press.

Harris, Alice C. 1991. “Mingrelian.” In The Indigenous Languages of the Caucasus. Vol. 1: The Kartvelian Languages, ed. Alice C. Harris, 313-394. Delmar, NY: Caravan Books.

Holt, Nancy, ed. 1979. The Writings of Robert Smithson: Essays with Illustrations. New York: New York University Press.

Humphrey, Caroline. 2003. "Stalin and the Blue Elephant: Paranoia and Complicity in Post-Communist Metahistories.” In West and Sanders 2003, 175-203.

Humphrey, Caroline, ed. 2018. Trust and Mistrust in the Economies of the ChinaRussia Borderlands. Amsterdam: Amsterdam University Press. 
Khalvashi, Tamta. 2014. "Capturing Marginality: The Social Role of Photography in the Wake of Rapid Urban Development in Batumi, Adjara." Caucasus Analytical Digest 66: 10-13.

Laszczkowski, Mateusz. 2016. 'City of the Future': Built Space, Modernity and Urban Change in Astana. New York: Berghahn Books.

Ledeneva, Alena V. 1998. Russia's Economy of Favours: Blat, Networking and Informal Exchange. Cambridge: Cambridge University Press.

Lepselter, Susan. 2016. The Resonance of Unseen Things: Poetics, Power, Captivity, and UFOs in the American Uncanny. Ann Arbor: University of Michigan Press.

Liisberg, Sune, Esther Oluffa Pedersen, and Anne Line Dalsgård, eds. 2015. Anthropology and Philosophy: Dialogues on Trust and Hope. New York: Berghahn Books.

Mair, Jonathan, Ann H. Kelly, and Casey High. 2012. "Introduction: Making Ignorance an Ethnographic Object.” In The Anthropology of Ignorance: An Ethnographic Approach, ed. Casey High, Ann H. Kelly, and Jonathan Mair, 1-32. New York: Palgrave Macmillan.

Marcus, George E., ed. 1999. Paranoia within Reason: A Casebook on Conspiracy as Explanation. Chicago: University of Chicago Press.

Merriam-Webster. 1984. Webster's New Dictionary of Synonyms: A Dictionary of Discriminated Synonyms with Antonyms and Analogous and Contrasted Words. Springfield, MA: Merriam Webster.

Merriam-Webster. n.d. “Trojan horse.” https://www.merriam-webster.com/dictionary/Trojan \% 20horse.

Mühlfried, Florian. 2018. "Introduction: Approximating Mistrust." In Mistrust: Ethnographic Approximations, ed. Florian Mühlfried, 7-22. Bielefeld: transcript.

Mühlfried, Florian. 2019. Mistrust: A Global Perspective. Basingstoke: Palgrave Pivot.

Pedersen, Morten Axel. 2013. "The Fetish of Connectivity.” In Objects and Materials: A Routledge Companion, ed. Penny Harvey, Eleanor Conlin Casella, Gillian Evans, et al., 197-207. London: Routledge.

Pelkmans, Mathijs. 2003. "The Social Life of Empty Buildings: Imagining the Transition in Post-Soviet Ajaria.” Focaal 41: 121-136.

Pelkmans, Mathijs. 2013. "Outline for an Ethnography of Doubt.” In Ethnographies of Doubt: Faith and Uncertainty in Contemporary Societies, ed. Mathijs Pelkmans, 1-42. London: I.B. Tauris.

Pelkmans, Mathijs, and Rhys Machold. 2011. "Conspiracy Theories and Their Truth Trajectories.” Focaal 59: 66-80.

Sanders, Todd. 2003. "Invisible Hands and Visible Goods: Revealed and Concealed Economies in Millennial Tanzania.” In West and Sanders 2003, 148-174.

Saxer, Martin, and Ruben Andersson. 2019. "The Return of Remoteness: Insecurity, Isolation and Connectivity in the New World Disorder." Social Anthropology 27 (2): 140-155.

Stewart, Kathleen. 1999. “Conspiracy Theory's Worlds.” In Marcus 1999, 13-19.

Stoller, Paul, and Cheryl Olkes. 1987. In Sorcery's Shadow: A Memoir of Apprenticeship among the Songhay of Niger. Chicago: University of Chicago Press. 
Strathern, Marilyn. 2014. "Reading Relations Backwards." Journal of the Royal Anthropological Institute 20 (1): 3-19.

Sztompka, Piotr. 1999. Trust: A Sociological Theory. Cambridge: Cambridge University Press.

West, Harry G., and Todd Sanders, eds. 2003. Transparency and Conspiracy: Ethnographies of Suspicion in the New World Order. Durham, NC: Duke University Press.

Wiegratz, Jörg. 2016. "Introduction: Rethinking Moral Economy: Capitalism and the Question of Morals.” In Neoliberal Moral Economy: Capitalism, Socio-Cultural Change and Fraud in Uganda, 1-18. London: Rowman \& Littlefield.

Yurchak, Alexei. 2006. Everything Was Forever, Until It Was No More: The Last Soviet Generation. Princeton, NJ: Princeton University Press.

Zigon, Jarrett. 2014. "Attunement and Fidelity: Two Ontological Conditions for Morally Being-in-the-World.” Ethos 42 (1): 16-30. 